\title{
Tahıl üretim alanlarında sarı cücelik virüs hastalıkları (Yellow dwarf virus diseases) epidemisi ve mücadelesi
}

\author{
$\underline{\text { Havva ÍLBAĞI }}$
}

\author{
ABSTRACT \\ Epidemic of yellow dwarf virus diseases in cereal growing areas and their \\ control
}

Yellow dwarf virus (YDVs) diseases are one of the most important diseases which have reduced crop yield and quality in the cereal growing areas by causing epidemics from time to time on all over the world as well as in Turkey. Just as prevailing in some potential cereal producer provinces of Turkey as well as in Edirne, Kırklareli and Tekirdağ provinces of Trakya Region during the year of 2016, yellow dwarf virus epidemic diseases were taken place. Those virus diseases in cereal fields have become widespread especially in wheat fields which have reduced the yield and quality and caused economic losses. Survey studies were conducted and observation on YDVs disease epidemics in cereal fields especially in Edirne, Kirklareli and Tekirdağ provinces. At least 187 plant leaf samples were collected from the symptomatic winter bread wheat, barley and oat plants exhibiting yellowing, dwarfing, reddish symptoms and signs in the cereal growing areas. So, beside 138 bread wheat (Triticum aestivum L.), 19 barley (Hordeum vulgare L.) and 10 oat (Avena sativa L.) leaf samples, 20 samples were obtained from the perennial Poaceae weed host common reed (Phragmites austrialis (Cav.) Trin ex. Steudel). Barley yellow dwarf virus-PAV (BYDVPAV), Barley yellow dwarf virus-MAV (BYDV-MAV) and Cereal yellow dwarf virus-RPV (CYDV-RPV) from YDVs were searched by employing double antibody sandwich enzyme linked immunosorbent assay (DAS-ELISA) test. Reverse transcription polymerase chain reaction (RT-PCR) test was implemented for suspected leaf samples. As a result of DASELISA and RT-PCR tests, 89 out of 187 leaf samples at the rate of $47.59 \%$ were found infected with BYDV-PAV. As 30 samples at the rate of $16.04 \%$ had CYDV-RPV and 4 of 187 leaf samples at rate of $2.14 \%$ were infected with BYDV-MAV viruses individually. Merely 14 out of 187 leaf samples at the rate of $48 \%$ were found infected with these tested YDVs (BYDV-PAV, BYDV-MAV and CYDV-RPV) as mixed infections. During the year of 2016, YDVs infections were determined at the highest level of incidence rate being $36.89 \%$ in the cereal growing areas of Edirne province. As in Kirklareli, YDVs incidence

\footnotetext{
${ }^{1}$ Namık Kemal Üniversitesi, Ziraat Fakültesi, Bitki Koruma Bölümü, 59030, Tekirdağ Sorumlu yazar (Corresponding author) e-mail: hilbagi@nku.edu.tr Alınış (Received): 19.04.2017, Kabul ediliş (Accepted): 10.05.2017
} 
rate was $21.93 \%$ and in Tekirdağ province, incidence rate of YDVs was determined as $14.44 \%$. Effective and appropriate control measures against YDVs infections were determined with previous researches. So cereal producers, farmers and the other beneficiaries of food production sector in the Trakya Region have been informed steadily.

Keywords: Cereal, YDVs, BYDV, CYDV, control

\section{$\ddot{\mathbf{O Z Z}}$}

Dünyada olduğu gibi Türkiye'deki tahıl üretim alanlarında da zaman zaman epidemiler oluşturarak verim ve kalite kayıplarına neden olan sarı cücelik virüslerinin (yellow dwarf virus, YDVs) neden olduğu hastalıklar tahılların en önemli hastalıkları arasındadır. 2016 yılı üretim döneminde, Türkiye'nin tahıl üretim potansiyeli yüksek olan illerinde de görüldüğü gibi, Trakya Bölgesi'nin Edirne, Kırklareli ve Tekirdağ illerindeki tahıl üretim alanlarında sarılık ve cüceliğe neden olan bu hastalıkların epidemileri meydana gelmiştir. Tahıl tarlalarında zaman zaman yaygın hale gelen bu virüs hastalıkları başta buğday olmak üzere tüm tahıl türlerinde verim ve kaliteyi düşürerek ekonomik kayıplara neden olmaktadır. YDVs hastalık epidemisinin görüldüğü Edirne ili başta olmak üzere Kırklareli ve Tekirdağ illerindeki tahıl tarlalarında arazi gözlemleri yapılmıştır. Hastalanan bitkilerin sergilediği sarılık, cücelik ve kızarıklık belirtilerinin görüldüğü kışlık buğday, arpa ve yulaf üretim alanlarından 187 adet enfekteli bitki yaprak örneği toplanmıştır. 138 buğday (Triticum aestivum L.), 19 arpa (Hordeum vulgare L.), 10 adet yulaf (Avena sativa L.) yaprak örneği ile birlikte YDVs'nin konukçusu çok yıllık Poaceae yabanc1 ot türü kamış (Phragmites austrialis (Cav.) Trin ex.Steudel)'tan da 20 adet yaprak örneği toplanmıştır. Enfekteli yaprak örneklerinde, YDVs'den Barley yellow dwarf virus-PAV (BYDV-PAV), Barley yellow dwarf virus-MAV (BYDV-MAV) ve Cereal yellow dwarf virus-RPV (CYDV-RPV) öncelikle double antibody sandwich enzyme linked immunosorbent assay (DAS-ELISA) testi ile araştırılmıştır. Enfekteli olduklarından şüphelenilen örnekler reverse transcription polymerase chain reaction (RT-PCR) testine tabi tutulmuştur. DAS-ELISA ve RT-PCR testleri sonucu toplam 187 adet örnekten 89 adedinde ve $\% 47.59$ oranında BYDV-PAV; 30 örnekte \%16.04 oranında CYDV-RPV ve 4 örnekte ise \%2.14 oranında BYDV-MAV virüsleri bireysel olarak saptanmıştır. Bunun yanısıra 187 adet örnekten 14 adedinde ve \%7.48 oranında ise YDVs (BYDV-PAV, BYDV-MAV ve CYDV-RPV)'nin karışık enfeksiyonları saptanmıştır. 2016 yılında Edirne ilindeki tahıl üretim alanlarında YDVs enfeksiyonu \%36.89 ile en yüksek orana sahipken Kırklareli'nde \%21.93, Tekirdağ ilinde ise bu oran \%14.44 olarak tespit edilmiştir. YDVs ile etkin ve uygulanabilir mücadele yöntemleri, önceki çalışmalarla saptanmıştır. Trakya Bölgesindeki tahıl üreticileri, çiftçiler ve sektörün diğer paydaşları hastalık etmenleri ve mücadelesi ile ilgili olarak sürekli bilgilendirilmektedir.

Anahtar kelimeler: Tahıl, YDVs, BYDV, CYDV, mücadele

\section{GİRIȘ}

Tahıllarda sarı cücelik virüs hastalıkları (yellow dwarf viruses, YDVs) dünyada yaygın şekilde görülen ekonomik öneme sahip virüs hastalıklarıdır. Son yıllarda da Türkiye'deki tahıl üretim alanlarında sıklıkla görülen hastalıklar olarak ortaya çıkmıştır. Tahıllarda verim ve kalite kayıplarına neden olarak yıkıcı zararlar 
oluşturan YDVs Poaceae familyasına mensup çok geniş bir konukçu dizisine sahiptir. Bu virüsler başta buğday olmak üzere arpa, yulaf, çavdar, darı, tritikale, mısır, çeltik ve sorgumda hastalığa neden olur ve dane verimini önemli ölçüde düşürür. Bunun dışında konukçusu olan 150 türden fazla çayır mera ve çim bitkilerinde de ot verimini düşürmektedir (Gould and Shaw 1983). Global düzeyde tahıl üretimi yapılan alanlarda verim ve kalite kayıplarına neden olan YDVs ilk defa 1951 yilında ABD'de, Kaliforniya'da Oswald and Houston $(1951,1953)$ tarafindan rapor edilmiştir. Daha sonra 1954 yılında Avrupa'da Oswald tarafindan Hollanda'da tanımlanmış ve 1957 yılında ise İngiltere'de Watson and Mulligan (1957) tarafindan teyit edilmiştir. 1961 yllında Rochow and Norman (1961) ise ABD'nin kuzey eyaletlerinde başta arpa olmak üzere serin iklim tahıllarında görülen hastalığın epidemiler yaptığını gözlemlemişler ve Arpa sarı cücelik [Barley yellow dwarf virus, (BYDV)] hastalı̆̆ adını vermişlerdir. Bu çalışmayı takiben BYDV ilk defa Rochow and Brakke (1964) tarafindan arılaştırılarak virionları elektron mikroskopta incelenmiş ve virion boyutlarının 25-30 nm çapındaki ikosahedral (20 yüzlü) şekilde olduklarını saptamışlardır. Duyarlı konukçu bitkilerin floem dokusu içerisinde dağıldıkları ve kuş kirazı afidi, Rhopalosiphum padi, başta olmak üzere pek çok yaprakbiti türü tarafindan persistent, ancak vektör bünyesinde çoğalmaksızın (nonpropagative) etkin bir şekilde taşındıkları bildirilmiştir. Rochow (1969) vektör türlerine göre 1rk ve tür farklılığı gösteren Arpa sarı cücelik virüslerinin bu özelliklerinin bir tesadüf değil bu virüsleri birbirinden ayırmak için güvenilir bir kural olduğunu ve hastalığın tarla koşullarında yayılmasını sağlayan yaprakbiti türlerine göre özelleşmiş 4 farklı virüs ırkının bulunduğunu bildirmiştir. Rochow and Muller (1971) ise vektör yaprakbiti türlerine göre özelleşmiş 5 farklı Barley yellow dwarf virus (BYDV) ırkı tanımlamışlardır. Bunlardan sırası ile BYDV-PAV'ın Rhopalosiphum padi ve Sitobion avenae; BYDV-MAV'in Macrosiphum (Schizaphus) graminum; BYDV-SGV'nin Sitobion avenae; BYDV-RMV'nin Rhopalosiphum maidis ve son olarak BYDV-RPV'nin de sadece Rhopalosiphum padi ile etkin bir şekilde taşındığını rapor etmişlerdir. Bu gruba daha sonra Rhopalosiphum padi ve Sitobion avenae tarafindan taşınan BYDV-PAS eklenmiştir.

YDVs'nin ırk ve tür tanıları, sadece onları tarla koşullarında taşıyan yaprakbiti türlerine göre değil son zamanlarda virüslerin genom yapılarındaki nükleotid dizi analizleri sonucu saptanan farklılıklara göre yapılmaya başlamıştır. Böylece yeni konukçulara özgü yeni yaprakbiti türleri tarafindan taşınan ve farklı coğrafik bölgelere adapte olan izolatların eklenmesi ile YDVs'nin tür sayıları artmaya devam etmektedir. Önceleri BYDVs olarak adlandırılan YDVs, Luteoviridae familyasına mensup dünyadaki tahıl virüslerinin geniş bir grubunu oluşturmaktadır. Nitekim önce D'Arcy and Domier (2005) daha sonra Domier (2012) tarafından özellikleri saptanan YDVs, Luteoviridae familyasına mensup iki cins içerisinde sınıflandırılmıştır. Bu virüslerden BYDV-PAV, BYDV-MAV ve BYDV-PAS kesin olarak Luteovirus cinsi içerisinde yer almaktadırlar. BYDV-GPV, BYDV-RMV, BYDV-SGV ile yeni tanımlanıp isimlendirilen Wheat yellow dwarf virus (WYDV) için bir cins tayini yapılmamıştır. YDVs'nin diğer grubu Polerovirus cinsi içerisinde 
New York kökenli Cereal yellow dwarf virus (CYDV-RPV) ve Meksika kökenli CYDV-RPS kesin olarak yer almışlardır. Ancak Çin Halk Cumhuriyeti'nde saptanan ve tanımlanan BYDV-GPV ırkının WYDV-GPV adı ile yine bu ülkede saptanan BYDV-GAV ırkının Polerovirus cinsi içerisinde yer alması önerilmiştir (Zhang et al. 2009). BYDV-RMV ırkını ise Maize yellow dwarf virus-RMV (MYDV-RMV) adı ile Polerovirus cinsi içerisinde yer alması gerektiği Krueger et al. (2013) tarafından önerilmiştir. Tür sayıları her geçen yıl artan YDVs'nin son sayısına ve sınıflandırmadaki yerine bakıldığında, Luteoviridae familyası içerisinde Luteovirus cinsinden BYDV-PAV, BYDV-MAV ve BYDV-PAS, Polerovirus cinsinden ise CYDV-RPS, CYDV-RPV, WYDV-GPV, MYDV-RMV, BYDV-GAV ve BYDVSGV olmak üzere toplam 9 türü bulunduğu görülmektedir. YDVs'nin ABD'de tanımlanıp, virüs türlerinin en az 25 farklı yaprakbiti vektörünün saptanmasından sonra bu konudaki çalışmalarda büyük bir artış olmuştur (D'Arcy and Burnett 1995). Vektöre göre özelleşme nitelikleri yanında bazı YDVs ırklarının tüm genomlarının da saptandığı, bu virüslerden WYDV-GPV virüsünün CYDV-RPV ile yakın ilişkili olduğu (Lucio-Zavaleta et al. 2001, Zhang et al. 2009); BYDV-PAV-CN izolatının ise diğer BYDV virüslerinden yüksek düzeyde farklılık gösterdiği belirlenmiştir (Liu et al. 2007). Vektöre göre özelleşmiş olan YDVs'nin farklı çevre koşulları altında değişebildikleri gibi vektör yaprakbiti türünün genotipinin de değişime uğrayabildiği bildirilmiştir (Lucio-Zavaleta et al. 2001). Bu nedenle son zamanlarda YDVs'nin veya izolatlarının bunları taşıyan yaprakbitinden ziyade genom organizasyonu ve nükleotid dizilerine göre sınıflandırılmasına öncelik verilmesinin yerinde olacağı önerilmiştir (Krueger et al. 2013).

Türkiye'de ise tahıl üretim alanlarında bazı yıllar epidemilere neden olduğu İlbağı (2003, 2013, 2017) ve İlbağı et al. (2008) tarafindan bildirilen YDVs'lerle ilgili ilk gözlemler Bremer and Raatikainen (1975) tarafindan Batı Anadolu'daki tahıl tarlalarında yapılmış olup, bu hastalığın yaprakbiti ile taşınan BYDV olabileceği ileri sürülmüştür. Daha sonra Yurdakul ve ark. (1987) İç Anadolu Bölgesinde buğdayda BYDV hastalığını simptomatolojik gözlemlerle ve biyolojik testlerle tespit etmeye çalışmış, ancak kesin tanı için serolojik testleri önermişlerdir. Bu iki bildirimden sonra, 1999 y1lında Trakya Bölgesinde Edirne'nin Uzgaç köyündeki kışlık ekmeklik buğday tarlalarında ilk defa YDVs epidemisi gözlenmiştir (İlbağı 2003). Aynı dönemde Özder ve Toros (1999) Trakya'da Tekirdağ ili buğday tarlalarında 7 tür yaprakbitinin bulunduğunu ve ürüne zarar verdiğini bildirmişlerdir. Türkiye'de yaygın şekilde üretilen tahıl türlerinde epidemi boyutlarına ulaşan YDVs kapsamlı bir şekilde Trakya Bölgesindeki tahıl türleri üzerinde araştırılarak virüslerin 1 rk ve tür düzeyinde tanıları ilk defa İlbağı (2003) tarafindan gerçekleştirilmiştir. Nitekim kışlık ekmeklik buğday (Triticum aestivum L.), arpa (Hordeum vulgare L.), yulaf (Avena sativa L), çavdar (Secale cereale L.), tritikale ve kuşyemi (Phalaris canariensis L.) tahıl türlerinde BYDV-PAV virüsü Edirne, Kırklareli ve Tekirdağ tahıl üretim alanlarında saptanmıştır (İlbağı 2003, İlbağı et al. 2005). Uluslararası Türk-Macar Projesi kapsamında Trakya Bölgesinin 2 ilindeki sarı cücelik hastalık etmeni virüs (BYDV-PAV, BYDV-SGV, BYDV-RMV ve 
CYDV-RPV) türleri ile buğday cücelik [Wheat dwarf virus (WDV)] virüsü tanılanmıştır. Aynı proje ile Türkiye'nin Çanakkale, Balıkesir, İzmir, Uşak, Afyon, Kütahya, Ankara, Konya, Nevşehir, Kayseri, Sivas, Tokat, Çorum, Ankara ve Eskişehir'i de içine alan 15 ilindeki kışlık ve yazlık buğday ve arpa üretim alanlarında da YDVs ve WDV virüsleri araştırılarak teşhis edilmiştir (İlbağı et al. 2003, Pocsai et al. 2003).

Türkiye'nin diğer bölgelerinde de sarı cücelik hastalıkları ve YDVs'lerinin varlığı araştırma konusu olmaya başlamıştır. Nitekim Çukurova Bölgesindeki dane mısır (Zea mays L.) üretim alanlarında BYDV hastalığının bulunduğu Fidan ve Yılmaz (2004) tarafından bildirilmiştir. Kırklareli ve Tekirdağ illerindeki silajlık mısır tarlalarında ise BYDV-PAV virüsü İlbağı et al. (2006) tarafından saptanmıştır. Bursa ilindeki şeker mısırı üretim alanlarında ise yine BYDV-PAV İlbağı ve Geyik (2014) tarafından tanılanmıș olup, BYDV-PAV'ın Samsun ilindeki mısır tarlalarında da görüldüğü Toksöz ve Kutluk Yılmaz (2016) tarafından bildirilmiştir. YDVs'nin yabancı ot konukçularından adi kamış (Phragmites communis Trin.)'da BYDV-PAV ilk kayıt olarak İlbağı (2006) tarafından saptanmıştır. Ardından kuşyemi (Phalaris canariensis L.)'nde BYDV-PAV ve CYDV-RPV ise yine İlbağ 1 et al. (2008) tarafından rapor edilmiştir. Samsun ili buğday tarlalarında BYDV-PAV ve BYDVMAV Erkan ve Kutluk (2009)'un çalışmaları ile Samsun ve Amasya illerinde BYDV-PAV ve BYDV-MAV türlerinin buğday ve arpa tarlalarındaki varlı̆g 1 Deligöz ve ark. (2011) tarafından saptanmıştır. Fidan ve ark. (2014), Kuzey Kıbrıs Türk Cumhuriyeti buğday tarlalarında BYDV-PAV, BYDV-MAV ve CYDV-RPV virüslerini tanıladıklarını ve vektörleri Rhopalosiphum padi ve Macrosiphum (Sitobion) avenae türlerini saptadıklarını bildirmişlerdir. Çapkan ve Paylan (2016) İzmir ve Aydın illerindeki buğday üretim alanlarında BYDV'yi saptamış, Usta ve ark. (2016) ise BYDV-PAV, BYDV-SGV, CYDV-RPV'yi Doğu Anadolu Bölgesindeki buğday alanlarında ilk kayıt olarak rapor etmişlerdir.

Gerek tahıl tarlalarında ve gerekse çayır-mera alanlarında ürüne zarar veren en önemli patojenler olan YDVs'nin doğal ortamlarda Poaceae yabancı ot türlerindeki ilk kapsamlı çalışmaları yine Trakya Bölgesi tahıl üretim alanlarında gerçekleştirilmiştir. YDVs'nin Poaceae yabancı ot konukçuları başta Phragmites austrialis, Lolium spp. ve Bromus spp. olmak üzere 40 farklı yabancı ot türünde BYDV-PAV, BYDV-MAV, BYDV-SGV, BYDV-RMV ve CYDV-RPV virüsleri saptanarak kısmi nükleotid dizileri belirlenmiş ve Uluslararası Gen Bankasındaki kayıtlı diğer YDVs izolatları ile yüksek düzeyde benzerlik gösterdikleri saptanmıştır (İlbağı et al. 2011, İlbağı ve ark. 2013a, İlbağı et al. 2013b). Yine aynı çalışmada Trakya Bölgesinde bu virüsleri, inokulum kaynaklarından tahıl tarlalarına taşıyan 7 farkl1 yaprakbiti türü Rhopalosiphum padi L., Rhopalosiphum maidis L., Sitobion avenea (Fab.), Schizapis graminum (Ron), Metopolophium dirhodum (Walker), Rhopalosiphum rufiabdominalis (Sasaki) ve Sitobion fragariae (Walker) olarak tanılanmıştır (İlbağ 1 ve ark. 2013a). Poaceae dışı yabancı otlardan Juncus compresus Jacq. ve Geranium dissectum L.'da; BYDV-PAV ve CYDV-RPV virüslerinin bulunuşu İlbağı ve ark. (2014) tarafından Türkiye'de ilk kayıt olarak rapor edilmiştir. 
YDVs, dünyada tahıl üretimi yapılan tüm alanlarda görülen en önemli virüs hastalıkları olup buğday, arpa ve yulafta \% 15-25 oranında verim kayıplarına neden olmaktadır (Lister and Ranieri 1995). Kışlık ekmeklik buğdaydaki verim kaybının ise ortalama \%33 oranında olduğu Perry et al. (2000) tarafindan bildirilmiştir. Bazı alanlarda bu oranın \%86'ya ulaşabildiği Miller and Rasochová (1997) tarafından rapor edilmiştir. Türkiye'de ise anıza erken ekim yapılan kışlık ekmeklik buğdayda $\% 20$ ile \%80 gibi yüksek oranlarda dane verimini düşürdükleri gibi verim ve kalite kriterlerini olumsuz şekilde etkiledikleri Dayan ve İlbağı (2014) tarafindan saptanmıştır. 2000 yılından itibaren Trakya Bölgesi tahıl tarlalarında YDVs'nin 5 ayrı ırkının tüm tahıl türlerinde ve yabancı ot konukçularında saptanmış olması bölgedeki tahıl üretim alanlarının bu hastalıklar nedeniyle tehdit altında olduğunu göstermiştir. Ancak Tekirdağ ilinde 2009-2013 yıllarında gerçekleştirilen proje çalışmaları ile YDVs hastalıkları ile mücadele yolları İlbağ belirlenmiştir. Elde edilen proje sonuçları Trakya Bölgesi üreticilerine, çiftçilere ve gıda sanayi sektörünün paydaşlarına 'Tahıllarda Sarı Cücelik Virüs Hastalıkları ile Mücadele Yöntemleri'” adı altında konferanslar ve broşürlerle duyurulmakta olup, bu eğitim faaliyetleri Tekirdağ'dan başlayarak Edirne Merkez ve ilçelerinde sürdürülmektedir (İlbağ 12017 ).

Küresel iklim değişikliği ve atmosferdeki ısınmanın 1lıman iklim kuşağında tarıma ve bitkisel üretime yansıyan olumsuz etkileri son yıllarda Türkiye'deki tahıl üretim alanlarında da hissedilmeye başlamıştır. Sürdürülebilir bitki koruma programları için ortaya çıkan bu iklim değişikliğinin agroekosistem üzerine de etki edebileceğini kabul etmek gerekir. Geçmişte bir yıl içerisinde farklı iklim koşulları ile 4 mevsim hüküm sürerken, şimdi sonbahar kış, ilkbahar ise yaz mevsimi koşulları içeren dönemler şeklinde gözlenmektedir. Bu durum bitki zararlılarının çoğalma şeklini, popülasyon dinamiklerini ve bitki hastalıklarının bulunuş oranlarını etkilemektedir. Benzer şekilde uçucu formdaki virüs vektörlerinin, bu virüsleri taşıyan vektör popülasyonlarında ve buna bağlı olarak viral hastalıkların bulunuş oranlarında önemli artışlar görülmüştür. Türkiye ile aynı enlemler arasında ve 1lıman iklim kuşağında yer alan Fransa'da, küresel iklim değişikliğinin özellikle Rhopalosiphum padi L. popülasyonlarında artışa neden olduğu; bu vektör türünün taşıdığı BYDVPAV'ın epidemiler yaptığı; yaprakbiti tuzaklarında yakalanan vektör sayılarının BYDV-PAV virüs hastalık bulunuş oranları ile korelasyon içerisinde olduğu Fabre et al. (2005) tarafından bildirilmiştir. 2000-2003 yıllarından itibaren Trakya Bölgesi tahıl üretim alanlarında periyodik olarak yapılan çalışmalarda YDVs hastalıklarının zaman zaman epidemilere neden olduğu belirlenmiştir (İlbağ 2003 , İlbağ ${ }_{1}$ et al. 2003, Pocsai et al. 2003, İlbağı ve Çıtır 2004a, 2004b, İlbağı et al. 2005, İlbağı 2006, İlbağ1 et al. 2006, İlbağ1 et al. 2008, İlbağ1 et al. 2011, İlbağ1 ve Çıtır 2012, İlbağ1 2013, İlbağı ve ark. 2013a, İlbağı et al. 2013b, İlbağ1 ve Çıtır 2014, İlbağ1 ve ark. 2014, İlbağ1 2016a, 2016b, 2016c, 2016d, 2016e). Nitekim 2016 y1l1 üretim döneminde Türkiye'nin tahıl üretim potansiyelinin yüksek olduğu illerinde görüldügü gibi Trakya Bölgesi tahıl tarlalarında da karakteristik virüs hastalıklarının şiddetli simptomlarını sergileyen epidemi olayları meydana gelmiştir. 2016 yılında 
Trakya Bölgesinde, kışlık ekmeklik buğday başta olmak üzere, arpa ve diğer tahıl türlerinde epidemiye neden olan virüslerin kesin teşhisini yapmak, ilgili kuruluşları ve çiftçileri bilgilendirmek ve hastalıkla ilgili mücadele önerilerini yeniden sunmak üzere bu çalışma gerçekleştirilmiştir. Bu çalışma ile Türkiye'nin birçok ilindeki tahıl tarlalarında görüldüğü gibi özellikle Trakya Bölgesinde epidemiye neden olan hastalık etmeninin tanısı yapılarak Gıda Tarım ve Hayvancılık Bakanlığına bir rapor sunulmuştur. Nitekim hastalığın teşhisinin yapılarak etmene yönelik mücadele yöntemlerinin uygun bir şekilde yerine getirilmesi bitkisel üretimin en önemli unsurlarındandır.

\section{MATERYAL VE METOT}

\section{Arazi ve sürvey çalışmaları}

2016 yılı üretim döneminde hastalığın epidemi yaptı̆̆ Trakya Bölgesi’nin Edirne ili başta olmak üzere Kırklareli ve Tekirdağ illerindeki tahıl üretim alanlarında arazi gözlemleri yapılmıştır. Hastalığın yaygın şekilde görüldüğü Edirne'den 82, Kırklareli'nden 45, Tekirdağ tahıl üretim alanlarından ise 60 adet olmak üzere sarılık, cücelik ve kızarıklık belirtisi sergileyen 138 buğday (Triticum aestivum L.), 19 arpa (Hordeum vulgare L.), 10 adet yulaf (Avena sativa L.) yaprak örneği alınmıştır. Ayrıca bölgede yaygın olarak bulunan çok yıllık yabancı ot türü kamış [Phragmites austiralis (Cav.) Trin ex. Steudel]'tan 20 adet örnek toplanmıştır. Hastalığın epidemi boyutlarına ulaştığı 2016 Nisan ayında Edirne ve Kırklareli Tarım İl Müdürlükleri, üretici ve çiftçiler tarafından teşhis edilmek üzere gönderilen 35 adet enfekteli buğday yaprak örneği ise çalışmaya dahil edilmemiş olup, ayrı değerlendirilmiş ve teşhis sonuçları ilgili il müdürlüklerine bildirilmiştir. Böylece çalışma materyali olarak 187 adet enfekteli yaprak örneği serolojik ve moleküler testler yapılıncaya kadar $-20^{\circ} \mathrm{C}$ 'de muhafaza edilmişlerdir.

\section{DAS-ELISA testi}

Trakya Bölgesinin Edirne, Kırklareli ve Tekirdağ illerinden alınan 187 adet yaprak örneğine BYDV-PAV, BYDV-MAV ve CYDV-RPV virüslerini saptamak üzere DAS-ELISA testi uygulanmıştır. PAV, MAV ve RPV virüslerinin antiserumları Agdia firmasından temin edilmiştir. DAS-ELISA testi Clark and Adams (1977)'in temel alındığ yöntem ile firmanın önerdiği protokole göre gerçekleştirilmiştir. DASELISA testi sonuçları, $405 \mathrm{~nm}$ dalga boyuna ayarlanmış Thermo-Multiskan FC marka ELISA okuyucusunda okutularak absorbans değerleri elde edilmiştir. Her bir virüs için negatif kontrollerin absorbans değerlerinin 2 katı ve daha fazla değer veren örnekler pozitif olarak kabul edilmiştir.

\section{RT-PCR testi}

Simptom gösteren ve enfekteli olduklarından şüphelenilen yaprak örneklerine RTPCR testi uygulanmıştır. 30 adet yaprak örneğinin total RNA ekstraksiyonları, RNaesy RNA Ekstraksiyon kiti (Qiagen, Almanya) protokolüne göre yapılmıştır. 
cDNA sentezi Fermentas firmasından temin edilen RevertAid First Strand cDNA sentez kiti ile gerçekleştirilmiştir. Çizelge 1'de gösterildiği üzere cDNA'lar her bir virüsün kılıf proteinine spesifik primer çiftleri kullanılarak çoğaltılmıştır. Her bir virüs için yapılan PCR testi $25 \mu 1$ toplam hacimde hazırlanmıştır. BYDV-PAV ve BYDV-MAV için yapılan PCR testinde $3 \mu 1$ 10x PCR buffer, $2 \mu \mathrm{MgCl}_{2}(25 \mathrm{mM})$, $1 \mu 1 \mathrm{dNTP}(10 \mathrm{mM}), 2 \mu 1$ Primer 1, $2 \mu 1$ Primer 2, $1 \mu 1$ Taq DNA polimeraz enzimi, $1 \mu 1$ cDNA ve $13 \mu 1$ RNase ari su hazırlanmıştır. CYDV-RPV için $3 \mu 1$ 10x PCR buffer, $2 \mu 1 \mathrm{MgCl}_{2}(25 \mathrm{mM}), 1 \mu 1 \mathrm{dNTP}(10 \mathrm{mM}), 0.5 \mu 1$ Primer 1, $0.5 \mu 1$ Primer 2, $0.3 \mu 1$ Taq DNA polimeraz enzimi, $2 \mu 1$ cDNA ve $15.7 \mu 1$ RNase ari su eklenmiştir. BYDV-PAV ve MAV PCR program $194^{\circ} \mathrm{C} 2 \mathrm{dk} ; 40$ döngü olarak $94^{\circ} \mathrm{C} 1 \mathrm{dk}, 43^{\circ} \mathrm{C} 1$ $\mathrm{dk}, 72^{\circ} \mathrm{C} 1 \mathrm{dk}$ ve son olarak $72^{\circ} \mathrm{C} 10 \mathrm{dk}$ olarak ayarlanmıştır. CYDV-RPV için PCR program $194^{\circ} \mathrm{C} 5 \mathrm{dk}$; 40 döngü olarak $94^{\circ} \mathrm{C} 30 \mathrm{sn}, 60^{\circ} \mathrm{C} 45 \mathrm{sn}, 72^{\circ} \mathrm{C} 1 \mathrm{dk}$ ve son olarak da $72^{\circ} \mathrm{C} 10 \mathrm{dk}$ olarak gerçekleştirilmiştir.

Çizelge 1. Sarı cücelik virüslerini RT-PCR testi ile tespit etmede kullanılan primer dizileri ve beklenen fragment uzunlukları

\begin{tabular}{|c|c|c|c|}
\hline Virüs adı & Primer dizisi (5'-3') & $\begin{array}{c}\text { Beklenen } \\
\text { bant } \\
\text { büyüklüğg̈ü } \\
\text { (bp) }\end{array}$ & Referans \\
\hline \multirow{2}{*}{$\begin{array}{l}\text { BYDV- } \\
\text { PAV }\end{array}$} & F-5'-CCAGTGGTTRTGGTC-3' & \multirow{2}{*}{531} & \multirow{2}{*}{$\begin{array}{l}\text { Robertson } \\
\text { et al. } \\
\text { (1991) }\end{array}$} \\
\hline & R-5'-GTCTACCTATTTGG -3' & & \\
\hline \multirow{2}{*}{$\begin{array}{l}\text { BYDV- } \\
\text { MAV }\end{array}$} & F-5'-CAACGCTTAACGCAGATGAA-3' & \multirow{2}{*}{175} & \multirow{2}{*}{$\begin{array}{l}\text { Deb and } \\
\text { Anderson } \\
\text { (2007) }\end{array}$} \\
\hline & R-5'-AGGACTCTGCAGCACCATCT-3' & & \\
\hline \multirow{2}{*}{$\begin{array}{l}\text { CYDV- } \\
\text { RPV }\end{array}$} & F-5'-ATGTTGTACCGCTTGATCCAC-3' & \multirow{2}{*}{400} & \multirow{2}{*}{$\begin{array}{l}\text { Deb and } \\
\text { Anderson } \\
(2007)\end{array}$} \\
\hline & R-5'-GCGAACCATTGCCATTG-3' & & \\
\hline
\end{tabular}

\section{SONUÇLAR VE TARTIŞMA}

2016 y1lı üretim döneminde Trakya Bölgesinin Edirne ve Kırklareli illerindeki kışlık buğday, arpa ve diğer tahıl türlerinde sarılık ve cücelik belirtisi sergileyen YDVs hastalıkları, Türkiye'nin tahıl üretim potansiyeli yüksek olan illerinde de benzer belirtilerle yaygın şekilde görülmüştür. Epidemiye neden olan hastalığı saptamak ve Trakya Bölgesindeki durumu tespit etmek amacıyla 2016 yılı Nisan ayında bölgede arazi gözlemleri yapılmıştır. Sarılık ve cücelik belirtisi sergileyen tahıl tarlalarında özellikle Edirne ilinin merkez köylerindeki tarlalarda epideminin yoğun olduğu görülmüştür (Şekil 1). Bölgede tahıl türleri içerisinde üretimi ilk sırada yer alan buğdayla beraber arpa, yulaf gibi diğer tahıl türlerinde de hastalığın yaygın olduğu gözlenmiştir. Tarla kenarlarındaki sarılık ve kızarıklık belirtisi sergileyen yabancı otların ise virüslerin inokulum kaynağı olarak varlığını sürdürdüğü YDVs'nin konukçusu yabancı ot türlerinden kamışlarda da aynı belirtiler gözlenmiştir (Şekil 2). 2000'li yıllardan itibaren başlayıp periyodik olarak günümüze kadar devam eden, 
Türkiye'nin 18 ilinde ve özellikle Trakya Bölgesindeki tahıl üretim alanlarında yaptığımız çalışmalarda YDVs'nin zaman zaman epidemilere neden olduğu belirlenmiştir (İlbağ1 2003, İlbağı et al. 2003, Pocsai et al. 2003, İlbağ1 ve Çıtır 2004a, 2004b, İlbağ1 et al. 2005, İlbağ1 2006, İlbağ1 et al. 2006, İlbağ1 et al. 2008, İlbağ1 et al. 2011, İlbağ1 ve Çıtır 2012, İlbağı 2013, İlbağı ve ark. 2013a, İlbağı et al. 2013b, İlbağı ve Çıtır 2014, Hamamcı ve ark. 2014, Dayan ve İlbağı 2014, İlbağ1 2016a, 2016b, 2016c, 2016d, 2016e). Nitekim bu çalışmada da 2016 yılında kışlik ekmeklik buğday başta olmak üzere arpa ve diğer tahıl tarlalarında yaygın şekilde görülen ve epidemiye neden olan hastalığın yine sarı cücelik virüs hastalıkları olduğu serolojik ve moleküler testlerle kanıtlanmıştır.

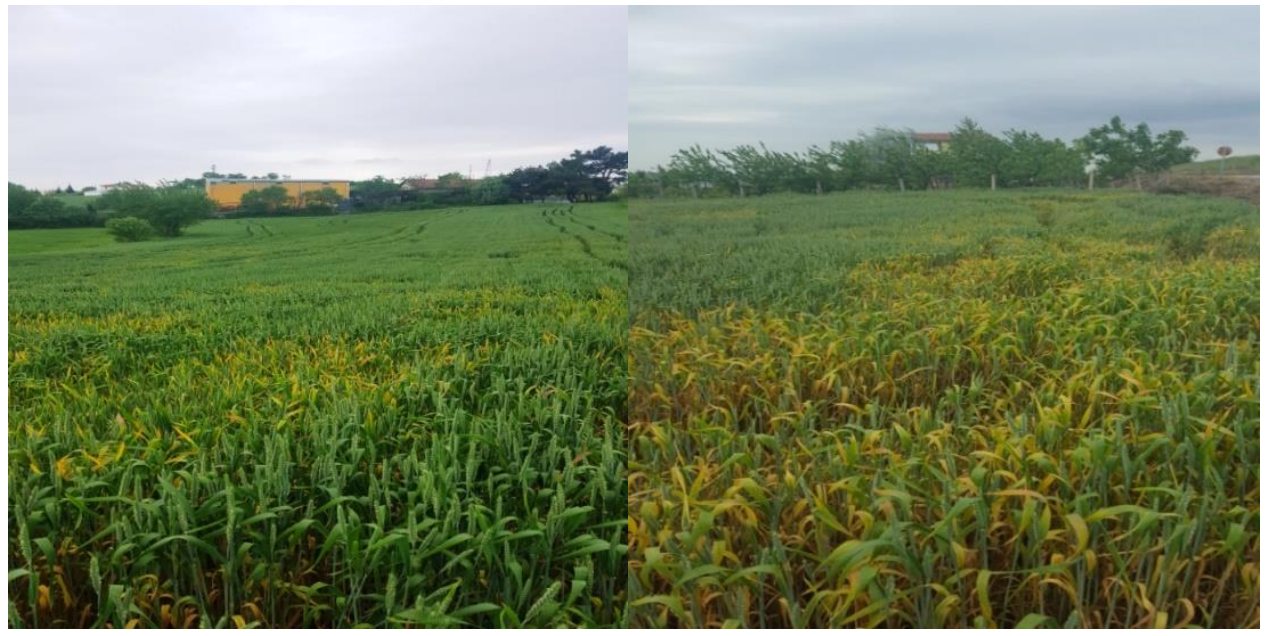

Şekil 1. Edirne ili merkez ilçeye bağlı Hıdırağa, Musabeyli ve Karayusuf köylerindeki buğday tarlalarında sarı cücelik virüslerinin (YDVs) neden olduğu epidemi.

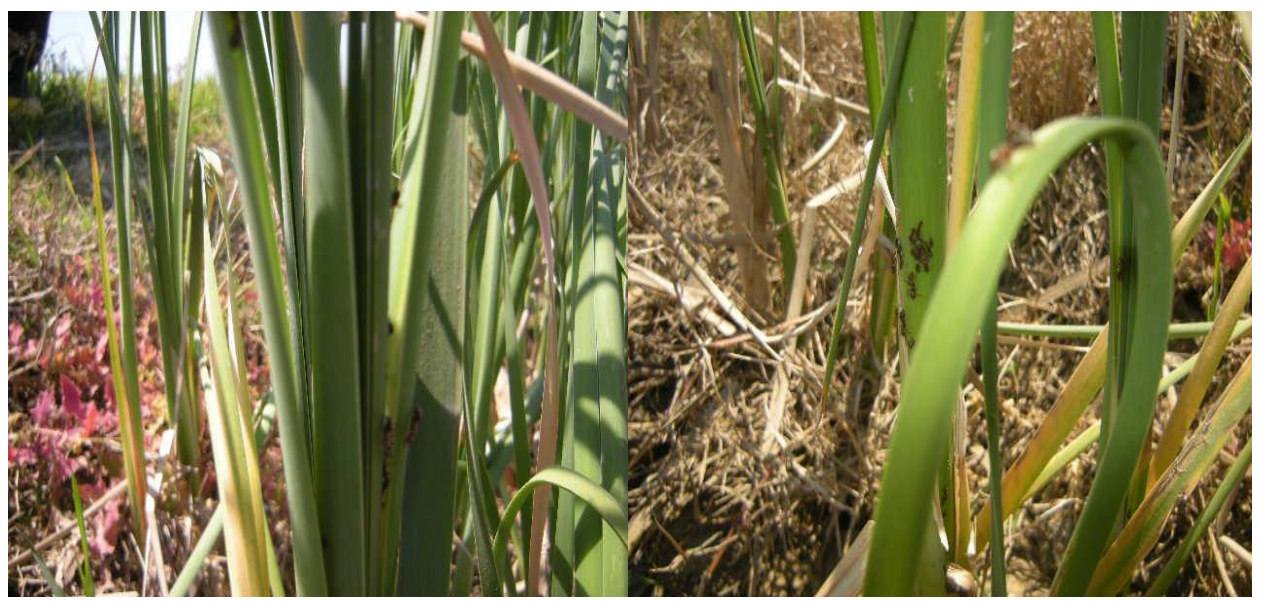

Şekil 2. Phragmites austrialis'de sarı cücelik virüsleri (YDVs)'nin neden olduğu kızarıklık solda) ve sarılık (sağda) belirtileri. 
Karakteristik virüs simptomları sergileyen 187 adet yaprak örneğine uygulanan DAS-ELISA test sonuçlarına göre 125 adet örnek YDVs'ne pozitif reaksiyon vermiştir. Simptom gösteren ve enfekteli olduklarından şüphenilen 30 adet örnek ise RT-PCR testine tabi tutulmuştur. RT-PCR test sonuçlarına göre 12 adet tahıl örneğinin YDVs'leri ile enfekteli oldukları saptanmıştır. Böylece Edirne ve Kırklareli illerinden alınan 6 adet buğday ve 3 adet arpa örneği BYDV-PAV ile enfekteli iken; Kırklareli ilinden alınan 1 adet buğday örneği BYDV-MAV ile enfekteli olarak bulunmuştur. Tekirdağ ilinden alınan 2 adet buğday örneğinin ise CYDV-RPV ile enfekteli olduğu tespit edilmiştir. Şekil 3, Şekil 4 ve Şekil 5'de görüleceği üzere RT-PCR testi sonucunda BYDV-PAV, BYDV-MAV ve CYDVRPV virüsleri için beklenen uzunluktaki bantlar elde edilmiştir.

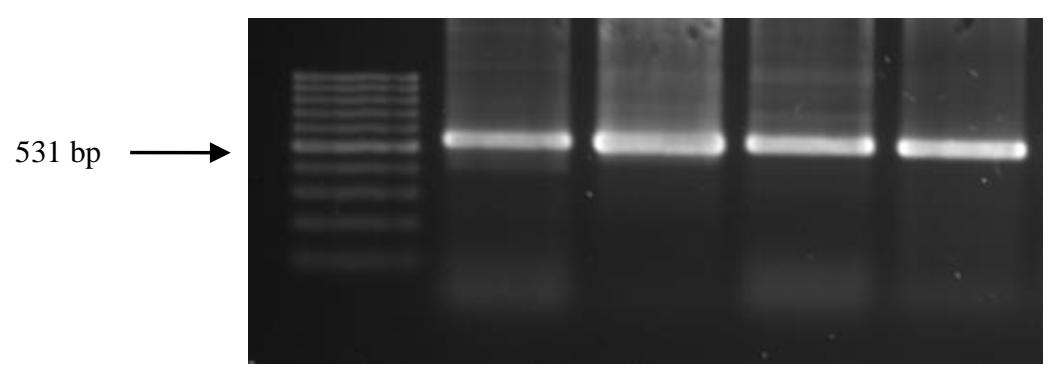

Şekil 3. Barley yellow dwarf virus-PAV (BYDV-PAV) ile enfekteli buğday ve arpa örneklerine ait 531 bp uzunluğundaki PCR amplifikasyonu sonucu elde edilen bantların görünümü.

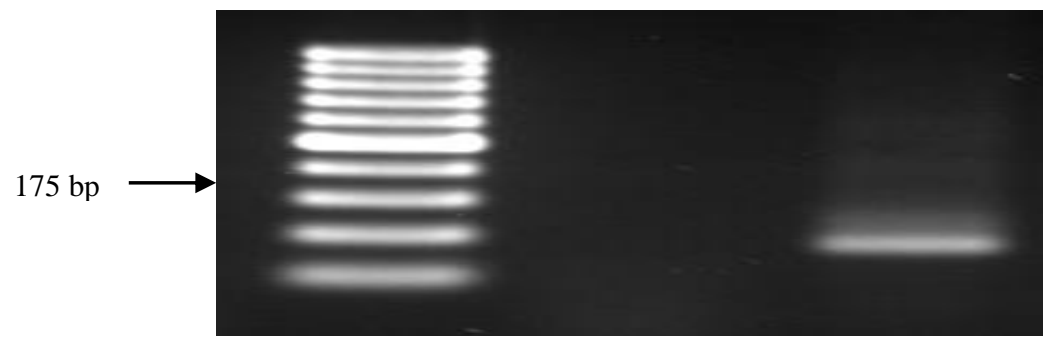

Şekil 4. Barley yellow dwarf virus-MAV (BYDV-MAV) ile enfekteli buğday örneklerine ait 175 bp uzunluğundaki PCR amplifikasyonu sonucu elde edilen bandın görünümü.

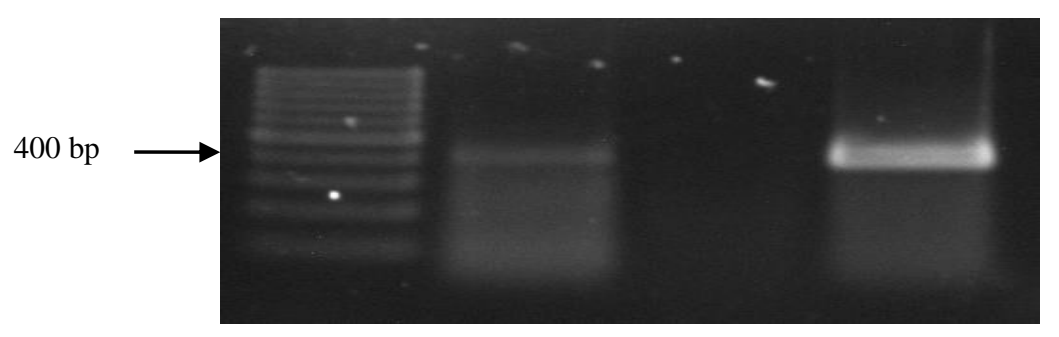

Şekil 5. Cereal yellow dwarf virus-RPV (CYDV-RPV) ile enfekteli buğday örneklerine ait 400 bp uzunluğundaki PCR amplifikasyonu sonucu elde edilen bantların görünümü. 


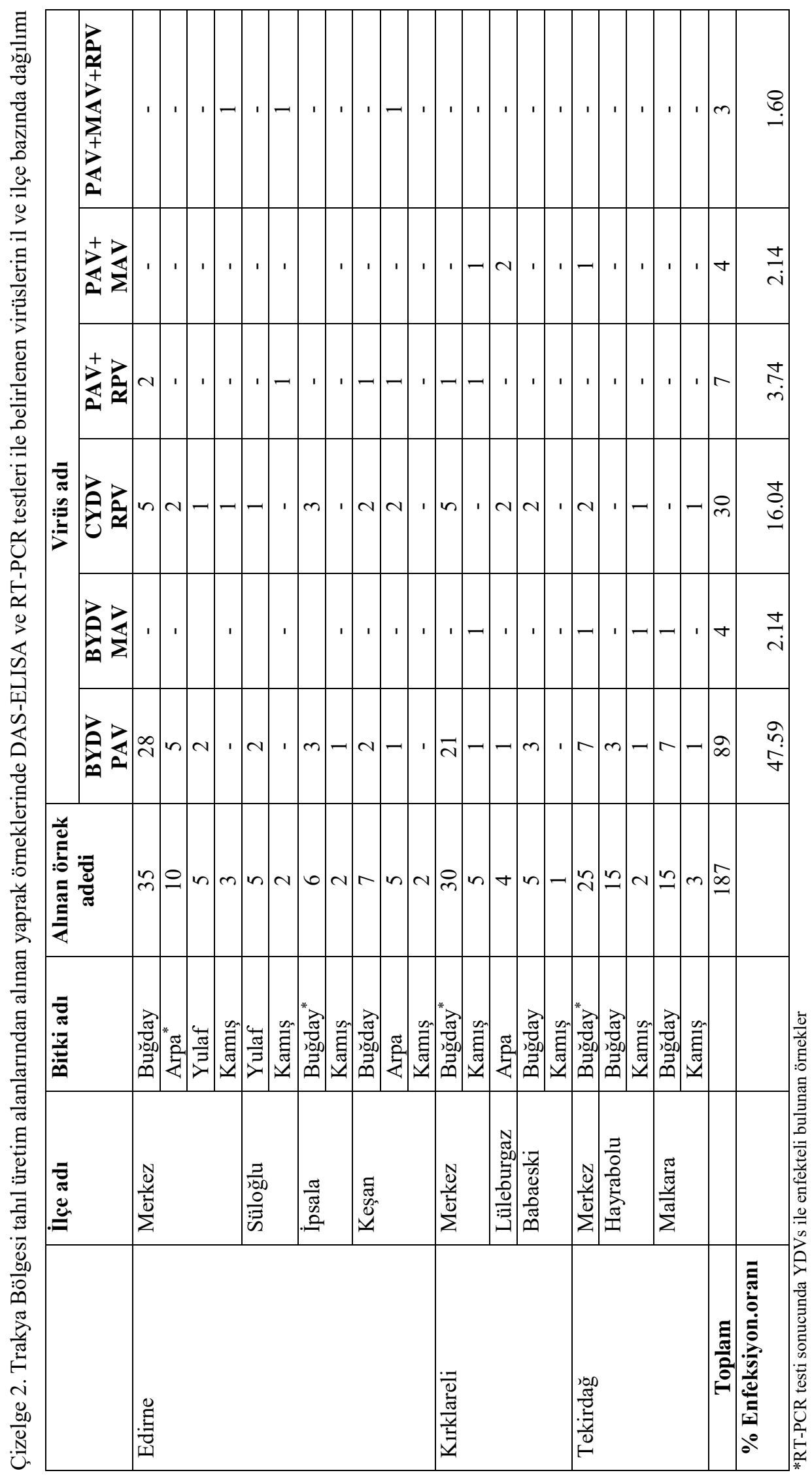


Çizelge 2'de görüleceği üzere 187 adet yaprak örneğinden 89'unun \%47.59 BYDV PAV, 30'unun \%16.04 CYDV-RPV, 4'ünün \%2.14 oranı ile BYDV-MAV ile enfekteli olduğu saptanmıştır. 14 örneğin ise \%7.48 oranında YDVs ile karışı enfeksiyonları tespit edilmiştir. Edirne ilindeki YDVs ile enfeksiyon oranı \%36.89 ile en yüksek orana sahipken, Kirklareli'nde \%21.93, Tekirdağ ilinde ise bu oran $\% 14.44$ olarak tespit edilmiştir. Bu sonuçlar doğrultusunda \%47.59 enfeksiyon oranı ile BYDV-PAV'ın baskın olduğu görülmektedir. Rhopalosiphum padi ve Sitobion avenae yaprakbiti türleri ile etkin bir şekilde taşınan BYDV-PAV'ın dominant ve en yaygın virüs irkı olduğu Rochow (1969), Rochow and Muller (1971) tarafindan bildirilmiştir. Nitekim vektör yaprakbiti türleri Trakya Bölgesinde Tekirdağ ilinde Özder ve Toros (1999) tarafından, bölge çapında ise İlbağı ve ark. (2013a) tarafindan saptanmış olup, BYDV-PAV başta olmak üzere YDVs'nin oluşturduğu sarı cücelik virüs hastalık epidemisinin 2016 yılında da tekrar görüldüğü bu çalışma ile kanıtlanmıştır. İlbağ1 (2003), İlbağ1 et al. (2005), İlbağ et al. (2008), İlbağ1 (2013) tarafından, Türkiye'nin Çanakkale, Balıkesir, İzmir, Afyon, Kütahya, Ankara, Konya, Nevşehir, Kayseri, Sivas, Tokat, Eskişehir, Kırklareli ve Edirne illerindeki tahıl tarlalarında da BYDV-PAV'ın baskın 1rk olduğu İlbağı et al. (2003) ve Pocsai et al. (2003) tarafından saptanmıştır. Aynı şekilde Samsun ili buğday tarlalarında Yılmaz ve Kutluk (2009), yine Samsun ve Amasya ili buğday ve arpa tarlalarında Deligöz ve ark. (2011) BYDV-PAV ve MAV ırklarını, Kuzey Kıbrıs Türk Cumhuriyetindeki tahıl tarlalarında Fidan ve ark. (2014) BYDV-PAV'1, İzmir ve Aydın ilinde buğdayda Çapkan ve Paylan (2016) BYDV'yi, Usta ve ark. (2016) ise Doğu Anadolu Bölgesi'nde BYDV-PAV, BYDV-SGV ve CYDV-RPV virüslerini saptamışlardır. YDVs'nden CYDV-RPV \%16.04 oranı ile tahıl tarlalarında görülme sıklığı olarak ikinci baskın 1rk olup, İlbağ1 et al. (2003), Pocsai et al. (2003), İlbağ1 et al. (2008) ve İlbağı (2013) tarafından yapılan çalışmalarda da benzer sonuçlar elde edilmiştir. Her ne kadar bazı yıllarda ikinci baskın ırk olarak BYDV-MAV İlbağı ve ark. (2013a) ve İlbağı et al. (2013b) tarafindan Trakya Bölgesindeki YDVs'nin yabanc1 ot konukçularında saptanmış olsa da bu çalışmada sadece \%2.14 oranında enfeksiyon saptanmıştır. Bu durum yaprakbiti türlerine göre özelleşen YDVs'nin BYDV-MAV'1 etkin taşıyan yaprakbiti türlerinin 2016 yılı içerisinde yaygın olmadığı anlamına gelmektedir. 2000 yılı öncesinde tahıl tarlalarında yaygın şekilde görülmeyen bu virüslerin son yıllarda epidemik hale gelmesi, küresel isınmanın etkisiyle artan hava sıcaklığının virüsü taşıyan vektör yaprakbiti türlerinde popülasyon artışlarına neden olmuş ve buna bağlı olarak söz konusu virüsler tahıl üretim alanlarında yaygın şekilde görülmeye başlamıştır. Oswald and Houston (1953) tarafından dünyada hastalığın ilk kaydı Kaliforniya'da, Avrupa'da 1954 yılında Hollanda ve 1957 yılında İngiltere'de (Watson and Mulligan 1957) yapılıış ise de söz konusu virüslerin ilk isimlendirilmesi Rochow and Norman (1961) tarafından Barley yellow dwarf virus (BYDV) olarak yapılmıştır. Ancak BYDV virüslerinin partikül yapıları, 1rk düzeyindeki tanıları ve taşındığı yaprakbiti türlerine göre isimlendirilmesi Rochow and Brakke (1964), Rochow (1969), Rochow and Muller (1971) tarafından rapor edilmiştir. Türkiye'de ise tahıl tarlalarında görülen hastalığın BYDV olabileceği 1975 yılında Bremer and Raatikainen (1975) 
tarafindan belirtilere göre bildirilmiş olup biyolojik testlere dayalı olarak ise Yurdakul ve ark. (1987) tarafindan rapor edilmiştir. Ancak 2000 yılından itibaren Trakya Bölgesinde devam eden çalışmalar sonucunda başta buğday olmak üzere arpa, yulaf, tritikale, kuşyeminde YDVs'nden BYDV-PAV, BYDV-MAV, BYDVSGV, BYDV-RMV ve CYDV-RPV saptanmıştır (İlbağ 2003 , İlbağ1 et al. 2003, Pocsai et al. 2003, İlbağı ve Çıtır 2004a, 2004b, İlbağı et al. 2005, İlbağı 2006, İlbağı et al. 2006, İlbağı et al. 2008). Ayrıca YDVs'nin yabanc1 ot konukçularından Phragmites communis' in özellikle BYDV-PAV için inokulum kaynağı olduğu bildirilmiştir (İlbağı 2006). Trakya Bölgesindeki 40 farklı yabancı ot türünde de PAV, MAV, RMV, SGV ve CYDV-RPV ve bu virüsleri taşıyan 7 farklı yaprakbiti türünün de saptandığı rapor edilmiştir (İlbağ1 et al. 2011, İlbağ 1 ve ark. 2013a, İlbağ1 et al. 2013b, İlbağı ve Çıtır 2014, İlbağı ve ark. 2014). Bu çalışmada ise yabancı ot konukçularından kamış (Phragmites austiralis)'taki enfeksiyon oranı \%6.42 olarak belirlenmiştir. Tahıl üretim alanlarında dünyada yaygın şekilde görülen YDVs'nin buğday, arpa ve yulafta \%15-25 oranında (Lister and Ranieri 1995), kışlık ekmeklik buğdayda \%33 oranında (Perry et al. 2000), bazı alanlarda ise \%86'ya kadar ulaşabildiği (Miller and Rasochová 1997) bildirilmiştir. Türkiye'de yapılan çalışmalarda ise YDVs'nin kışlık ekmeklik buğdayda \%20 ile \%80 gibi yüksek oranlarda dane verimini düşürdükleri gibi verim ve kalite kriterlerini de olumsuz etkiledikleri bildirilmiştir (Dayan ve İlbağı 2014). Nitekim Tekirdağ ilinde kuşyeminde $\% 61.63$, buğdayda $\% 32.33$, arpada $\% 26.52$, yulafta $\% 8.32$, tritikale'de ise $\% 8$ oranında verim kayıplarına neden olduğu tespit edilmiştir (İlbağı 2003, İlbağ1 et al. 2005).

Sonuç olarak küresel ısınmanın etkisini gösterdiği son yıllarda artan hava sıcaklıkları yaprakbiti ile taşınan bu virüs hastalıklarının artış göstereceğine işaret etmektedir. Nitekim 2000 yıllarından itibaren periyodik olarak yaptığımız çalışmalarda bu virüs hastalıklarının zaman içerisinde yaygın hale geleceği tespit edilmiştir. Bunun üzerine ekonomik olarak büyük önem taşıyan ve özellikle buğday başta olmak üzere arpa ve yulaf tarlalarında önemli oranda verim ve kalite kayıplarına neden olan bu hastalıklar ile mücadele yolları Trakya Bölgesinde 2009-2013 yılları arasında yapılan proje çalışmaları ile belirlenmiştir (İlbağ 12013 , 2017). Trakya Bölgesinde zaman zaman epidemilere neden olarak verim ve kalite kayıpları oluşturan bu hastalıklara çözüm bulmak üzere Tekirdağ Valiliği, İl Özel İdaresince desteklenen projede 3 yıl süren tarla denemeleri ve laboratuvar çalışmaları yapılmıştır. Uygulamaya yönelik olarak yürütülen bu proje sonucunda sarı cücelik virüs hastalıkları ile mücadele yolları belirlenmiştir (İlbağı 2013, 2017). Sarı cücelik virüs hastalıkları ile mücadele önerileri hakkında 2013 yılından itibaren Trakya Bölgesi çiftçileri bilgilendirilmektedir. Önerilen yöntemleri uygulayan çiftçiler hastalıkla mücadelede başarılı olmuşlardır. Nitekim bu çalışma sonucunda da görüleceği üzere önceki epidemi dönemlerinde en yüksek sarı cücelik hastalık bulunuş oranlarına Tekirdağ'da rastlanırken 2016 yılı hastalık bulunuş oranı diğer illere göre daha az olmuştur. Türkiye'deki tahıl üretim alanlarında ileriki yıllarda da tekrar görülmesi muhtemel olan sarı cücelik virüs hastalıkları ile mücadele yollarının tüm tahıl üretici 
ve çiftçilerine benimsetilmesi önerilmektedir. Bu bağlamda Sarı cücelik virüs hastalıklarına karşı uygulanacak mücadele yöntemleri şu şekilde belirlenmiştir (İlbağ 1 2013, 2017). Kışlık tahıl ekimlerinde geç ekim tarihi önemlidir. Kışlık ekmeklik buğday ve diğer kışlık tahıllar kasım ayında ekilmelidir. Nitekim 3 yıl süren tarla denemeleri sonrasında Trakya Bölgesi için belirlenen ekim tarihi 10 Kasım - 30 Kasım tarihleri arası bir dönem olarak saptanmıştır. Buna göre kasım ayının ikinci haftasından itibaren ekimler yapılmalıdır (Şekil 3). Bu çalışma ile belirlenen tarihlerde ekim yapan çiftçiler sarı cücelik virüs hastalıkları ile mücadele de başarı sağlamaktadırlar.

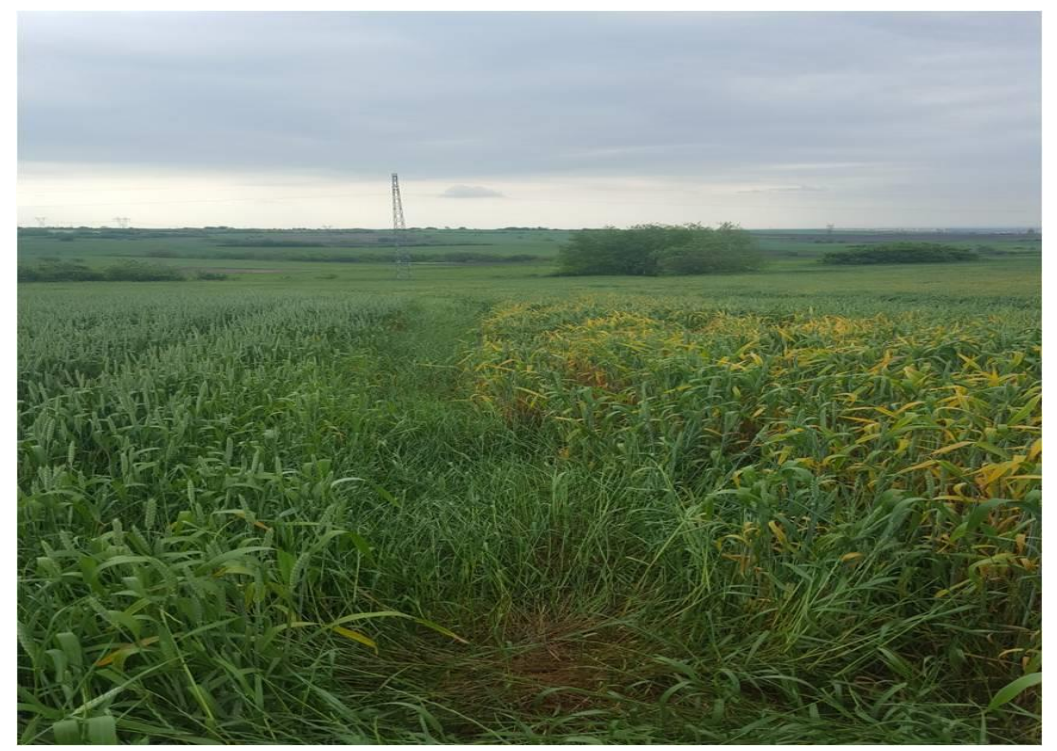

Şekil 6. Aynı üretim alanında geç ekimin (kasım ayı) yapıldığı soldaki tarlada hastalık görülmezken ekim ayında ekilen sağdaki tarlada ise Sarı cücelik virüs hastalığının buğday tarlasını önemli ölçüde etkilediği görülmektedir.

Uygun çeşit seçimi önemlidir. YDVs her tahıl türünde hastalığa neden olmaktadır. Yöreye adapte olmuş, verimi ve kalitesi üretici ve sektör tarafından olumlu değerlendirilmiş, hastalığa dayanıklı veya tolerant sertifikalı çeşitler ekilmeli ve her y1l farklı çeşitleri denemekten kaçınılmalıdır.

Ekim nöbeti mutlaka uygulanmalıdır. Buğday, arpa, yulaf, tritikale, çavdar, kuşyemi ve mısır üretiminde dane verimini düşüren, unun ve yemin kalitesini azaltan sarı cücelik virüs hastalıkları ile mücadelede ekim sıralaması yapmak ve ekim nöbeti uygulamak etkili bir mücadele şeklidir. Bu doğrultuda tahıl-yağ bitkisi (kanola veya ayçiçeği)-yem bitkisi (kışlık fiğ veya yem bezelyesi) ve tekrar tahıl sıralaması şeklinde üç yıllık ekim nöbeti uygulanmalıdır.

Kesinlikle anıza ekim yapılmamalıdır. Tarlaya üst üste buğday ekmekten veya buğday üstüne arpa, yulaf gibi bir başka tahıl ekmekten kaçınılmalıdır. Çünkü 
buğday hasadında dökülen daneler erken çıkış yapmakta, yaprakbitlerinin taşıdığı ve bulaştırdığı bu virüsler için hazır depo görevi görmektedir.

Trakya Bölgesinde çiftçiler çeşidi ne olursa olsun dekar başına atılması önerilen miktardan daha fazla tohum atmakta ve böylece birim alanda daha sik ve daha fazla sayıda tahıl bitkisi çıkış yaparak vektör yaprakbitlerinin bitkiden bitkiye geçişlerini kolaylaştırarak sarı cücelik virüslerinin yayılmasını ve hastalığın epidemi yapmasına uygun koşulları hazırlamaktadırlar. En bilinçli çiftçiler dahi dekara $18 \mathrm{~kg}$ olarak önerilen sertifikalı ekmeklik buğday tohumunu $26 \mathrm{~kg}$ olarak atmaktadırlar. Bunu ileri mekanizasyon ürünü hassas mibzerlerle yapmaları sonucu sarı cücelik virüs hastalıkları ile kök ve kök boğazı hastalıklarına yakalanmalarını kolaylaştırmakta ve böylece her iki hastalığın sinerjistik etkisi ile ürün kayıpları daha da artmaktadır.

Yabancı otlar ile mücadele edilmelidir. İyi bir toprak işleme ile tarlayı ekime hazırlarken ayrık, yabani yulaf, brom otu, kanyaş gibi yabancı otlar yok edilmelidir. Ayrıca herbisitlerle veya çapalama ile tarla kenarlarındaki Poaceae familyasından yabancı otlar ile mücadele edilmelidir. Virüslere ve onları tahıllara taşıyan yaprakbitlerine barınak görevi gören bu yabancı otlarla mücadele edilmezse sarı cücelik virüs hastalığına neden olan virüsler varlığını sürekli koruyacak ve hastalık her yil artacaktır.

YDVs ile mücadelede özellikle ekim tarihi ve yöreye uygun çeşit tercihi büyük önem taşımaktadır. Aynı şekilde diğer mücadele yollarının da usulüne uygun yerine getirilmesi önerilmektedir.

\section{KAYNAKLAR}

Bremer K. and Raatikainen M. 1975. Cereal disease transmitted or caused by aphids and leafhoppers in Turkey. Ann. Acad. Sai. Fenn. A. IV. Biologica, 203, 1-14.

Clark M.F. and Adams A.N. 1977. Characteristics of the microplate method of enzymelinked immunosorbet assay for the detection of plant viruses. Journal of General Virology, 34: 475-483.

Çapkan D. ve Paylan İ. 2016. Ege Bölgesi buğday üretim alanlarında Barley yellow dwarf virus (BYDV)'nin bulunma durumunun ve moleküler özelliklerinin belirlenmesi üzerinde araştırmalar. Uluslararası Katılımlı Türkiye VI. Bitki Koruma Kongresi, 5-8 Eylül Konya, $554 \mathrm{~s}$.

D'Arcy C.J. and Burnett P.A. (eds). 1995. Barley yellow dwarf: 40 years of progress. Am. Phytopathol. Soc. Press, St. Paul, MN.

D’Arcy C.J. and Domier L.L. 2005. Family Luteoviridae. pp. 891-900. In: Fauquet C.M., Mayo M.A., Maniloff J., Desselberger U., Ball L.A. (eds.) Virus taxonomy. VIIIth Report of International Committee on Taxonomy of Viruses. London UK. Elsevier Academic Press..

Dayan S. ve İlbağı H. 2014. Tekirdağ ili buğday ekim alanlarında ekmeklik buğday (Triticum aestivum L.) çeşitlerinde görülen tahıl virüs hastalıklarının buğday kalite özellikleri 
üzerine etkilerinin araştırılması. V. Türkiye Bitki Koruma Kongresi, 3-5 Şubat, Antalya, 283 s.

Deb M. and Anderson J.M. 2007. Development of a multiplexed PCR detection method for Barley and Cereal yellow dwarf viruses, Wheat spindle streak virus, Wheat streak mosaic virus and Soil-borne wheat mosaic virus. Journal of Virological Methods, 148: $17-24$.

Deligöz İ., Caner K.Y. ve Akyol H. 2011. Samsun ve Amasya illerinde buğday üretim alanlarında enfeksiyona neden olan Barley yellow dwarf virus-PAV ve Barley yellow dwarf virus-MAV virüslerinin araştırılması. Bitki Koruma Bülteni, 51 (2), 187-193.

Domier L.L. 2012. Family Luteoviridae. pp. 1045-1053. In: King A.M.Q., Adams M.J., Carstens E.B., Lefkowitz E.J. (eds.) Virus taxonomy, $9^{\text {th }}$ report of the international committee on taxonomy of viruses. Elsevier, Academic Press, San Diago CA, USA.

Erkan E. ve Kutluk N.D. 2009. Determination of virus diseases on wheat growing areas of Samsun province. Anadolu Tarım Bilimleri Dergisi, 24 (2), 67-75.

Fabre F., Plantegenest M., Mieuzet L., Dedryer C.A., Leterrier J.L. and Lacquot E. 2005. Effects of climate and land use on the occurrence of viruliferous aphids and the epidemiology of Barley yellow dwarf disease. Agriculture Ecosystems \& Environment, 106: 49-55.

Fidan H. ve Yılmaz M.A. 2004. Çukurova Bölgesi mısır ekim alanlarında zararlı spiroplasma ve önemli virüs hastalık etmenlerinin saptanması. Türkiye I. Bitki Koruma Kongresi Bildirileri, 8-10 Eylül, Samsun, $210 \mathrm{~s}$.

Fidan H., Güllü M. ve Gözüaçık C. 2014. Kuzey Kıbrıs Türk Cumhuriyeti tahıl üretim alanlarında Arpa sarı cücelik virüsü (Barley yellow dwarf virus, BYDV)'nün tespiti ve virüs-vektör ilişkilerinin belirlenmesi. Türkiye V. Bitki Koruma Kongresi, 3-5 Şubat, Antalya, 209 s.

Gould F.W. and Shaw R.B. 1983. Grass systematics. 2nd ed. Texas A\&M University Press, College Station, pp. 397.

Hamamcı G., Çıtır A. ve İlbağı H. 2014. Tekirdağ ilinde ekmeklik buğday (Triticum aestivum L.) alanlarında yaygın olarak görülen virüs hastalıklarına karşı bazı çeşitlerin reaksiyonlarının saptanması üzerine araştırmalar. V. Türkiye Bitki Koruma Kongresi, 3-5 Şubat, Antalya, $280 \mathrm{~s}$.

İlbağı H. 2003. Trakya Bölgesinde üretimi yapılan bazı buğday türlerinde verim kayıplarına neden olan viral kökenli enfeksiyonların etmenlerinin tanılanması. Doktora Tezi, Ege Üniversitesi, Fen Bilimleri Enstitüsü, 136 s.

İlbağı H., Pocsai E., Çııtır A., Muranyı I., Vida. G. and Korkut Z.K. 2003. Results of two years study on incidence of Barley yellow dwarf viruses, Cereal yellow dwarf virus$R P V$ and Wheat dwarf virus in Turkey. $3^{\text {rd }}$ International Plant Protection Symposium at Debrecen University, 15-16 October, Debrecen-Hungary, pp. 53-63.

İlbağı H. ve Çıtır A. 2004a. Türkiye'de tahıl virüs hastalıkları ve yayılış alanları. Türkiye I. Bitki Koruma Kongresi, 8-10 Eylül, Samsun, 176 s. 
İlbağı H. ve Çıtır A. 2004b. Türkiye'de Trakya Bölgesi'nde Barley yellow dwarf virus-PAV enfeksiyonlarının bazı buğday çeşitlerinde verime etkileri. Türkiye I. Bitki Koruma Kongresi, 8-10 Eylül, Samsun, $211 \mathrm{~s}$.

İlbağı H., Çıtır A. and Yorgancı U. 2005. Occurrence of virus infections on cereal crops and their identifications in the Trakya region of Turkey. Journal of Plant Diseases and Protection, 112: 313-320.

İlbaği H. 2006. The Common Reed (Phragmites communis Trin) is a natural host of important cereal viruses in the Trakya Region of Turkey. Phytoparasitica, 34: 441-448.

İlbağı H., Rabenstein F., Habekuss A., Ordon F. and Çıtır A. 2006. Incidence of virus diseases in maize fields in the Trakya region of Turkey. Phytoprotection, 87: 115-122.

İlbağı H., Rabenstein F., Habekuss A., Ordon F., Çıtır A., Cebeci O. and Budak H. 2008. Molecular, serological and aphid transmission studies of Barley yellow dwarf virus$P A V$ and Cereal yellow dwarf virus-RPV in Canary seed (Phalaris canariensis L.). Cereal Research Communications, 36: 225-234.

İlbağı H., Çıtır A., Uysal M. and Kara A. 2011. Incidence and molecular characterization of Barley yellow dwarf virus-PAV on Poaceae weeds in the Trakya region of Turkey. Plant Genomics European Meetings, May 4-7, İstanbul-Turkey, pp. 63.

İlbağı H. ve Çıtır A. 2012. Tekirdağ ilinde tahıllarda verim ve kaliteyi düşüren virüs hastalıklarının saptanması ve mücadele prensipleri. Yayınlanmış Çiftçi Broşürü.

İlbağı H. 2013. Tekirdağ ilinde tahıllarda verim ve kaliteyi düşüren virüs hastalıklarının saptanması ve mücadele yöntemlerinin araştırılması. Tekirdağ Valiliği, İl Özel İdaresi Destekli Projenin Sonuç Raporu, 150 s.

İlbağı H., Çıtır A., Kara A. ve Uysal M. 2013a. Trakya Bölgesi'nde tahıl üretim alanlarındaki yabanc1 otlarda görülen Sarı cücelik virüs hastalıklarının saptanması, karakterizasyonu ve afitlerle taşınabilirliklerinin belirlenmesi. TÜBİTAK Projesi Sonuç Raporu, 136 s.

İlbağı H., Çıtır A., Kara A. and Uysal M. 2013b. Poaceae weed host range of Luteoviridae viruses in the Trakya Region of Turkey. $16^{\text {th }}$ Symposium European Weed Research Society, Samsun-Turkey, June 24-27, pp. 98.

İlbağı H. ve Çıtır A. 2014. Farklı buğday çeşitlerinde Sarı cücelik virüs hastalıklarının saptanması ve moleküler karakterizasyonu. V. Türkiye Bitki Koruma Kongresi, 3-5 Şubat, Antalya, $282 \mathrm{~s}$.

İlbağı H. ve Geyik S. 2014. Türkiye'de Bursa ili mısır (Zea mays L.) tarlalarında görülen virüs hastalıklarının saptanması. Tekirdağ Ziraat Fakültesi Dergisi, 11 (1), 122-125.

İlbağı H., Çıtır A., Kara A. ve Uysal M. 2014. Türkiye'de tahıllarda Sarı cücelik virüsleri Barley yellow $d$ warf virus-PAV ve Barley yellow dwarf virus-MAV için yeni yabanc1 ot konukçuları Juncus compressus ve Geranium dissectum türlerinin ilk raporu. V. Türkiye Bitki Koruma Kongresi. 3-5 Şubat, Antalya, 281 s.

İlbağı H. 2016a. Edirne, Kırklareli ve Tekirdağ illerindeki tahıl üretim alanlarında Sar1 cücelik virüs hastalıklarının neden olduğu epidemi hakkında Gıda, Tarım ve Hayvancılık Bakanlığına sunulan rapor. 2 sayfa, tarih 29.04.2016. 
İlbağı H. 2016b.Türkiye'de tahıllarda verim ve kalite kayıplarına neden olan virüs hastalıkları. TÜRKTOB Dergisi, 39-42.

İlbağı H. 2016c. Trakya Bölgesi tahıl üretim alanlarında görülen Sarı cücelik virüs hastalıkları ve mücadele prensipleri. Tarım Türk Dergisi, 70-74.

İlbağı H. 2016d. Türkiye'de tahıl üretim alanlarında görülen Sarı cücelik virüs hastalıkları ve mücadele prensipleri. Tarla Sera Dergisi, 84-85.

İlbağı H. 2016e. Tahıllarda ekonomik kayıplara neden olan Sarı cücelik virüs hastalıkları ve mücadele prensipleri. TÜRKTOB Dergisi, 53-56.

İlbağı H. 2017. Trakya Bölgesinde tahıllarda verim ve kaliteyi düşüren virüs hastalıklarına karşı mücadele yolları. Yayınlanmış Çiftçi Broşürü.

Krueger E.N., Beckett R., Gray S.M. and Miller W.A. 2013. The complete nucleotide sequence of the genome of Barley yellow dwarf virus-RMV reveals it to be a new Polerovirus distantly related to other yellow dwarf viruses. Frontiers Microbiology, 4: 205.

Lister M.R. and Ranieri R. 1995. Distribution and economic importance of Barley yellow dwarf. pp. 29-53. In: D’Arcy C. J. and Burnett P. A. (eds.). Barley yellow dwarf: 40 years of progress. APS Press, MN.

Liu F., Wang X.F., Liu Y., Xie J.J., Gray S.M., Zhou G.H. and Gao B.D. 2007. A Chinese isolate of Barley yellow dwarf virus-PAV represents a third distinct species within the PAV serotype. Archives of Virology, 152: 1365-1373.

Lucio-Zavaleta E., Smith D. and Gray S. 2001.Variation in transmission efficiency among Barley yellow dwarf virus-RMV isolates and clones of the normally in efficient aphid vector, Rhopalosiphum padi. Phytopathology, 91: 792-796.

Miller W.A. and Rasochova L. 1997. Barley yellow dwarf viruses. Annual Revue of Phytopathology, 35: 167-190.

Oswald J.W. and Houston B.R. 1951. A new virus disease of cereals, transmissible by aphids. Plant Disease Reports, 35: 471-475.

Oswald J.W. and Houston B.R. 1953. The yellow dwarf disease of cereal crops. Phytopathology, 43: 128-136.

Özder N. ve Toros S. 1999. Tekirdağ ilinde buğdaylarda zarar yapan yaprak biti türlerinin saptanması üzerinde araştırmalar. Türkiye Entomoloji Dergisi, 23: 101-110.

Perry K.L., Kolb F.L., Sammons B., Lawson C., Cisar G. and Ohm H. 2000. Yield effects of Barley yellow dwarf virus in soft red winter wheat. Phytopathology, 90: 1043-1048.

Pocsai E., Çıtır A., İlbağı H., Köklü G., Muranyı I., Vida G. and Korkut Z.K. 2003. Incidence of Barley yellow dwarf viruses, Cereal yellow dwarf virus and Wheat dwarf virus in cereal growing areas of Turkey. Agriculture, 11: 583-591.

Robertson N.L., French R. and Gray S.M. 1991. Use of group-specific primers and the polymerase chain reaction for the detection and identification of Luteoviruses. Journal of General Virology, 72: 1473-1477. 
Rochow W.F. and Norman A.G. 1961. The Barley yellow dwarf virus disease of small grains. Adv.Agron., 13: 217-248.

Rochow W.F. and Brakke M.K. 1964. Purification of Barley yellow dwarf virus. Virology, 24: 310-322.

Rochow W.F. 1969. Biological properties of four isolates of Barley yellow dwarf virus. Phytopathology, 59: 1580-1589.

Rochow W.F. and Muller I. 1971. A fifth variant of Barley yellow dwarf virus in NewYork. Plant Dis.Rep., 55: 874-877.

Toksöz Y. ve Kutluk Yılmaz N.D. 2016. Samsun ilinde misır (Zea mays L.) üretim alanlarında enfeksiyon oluşturan virüslerin belirlenmesi. Anadolu Tarım Bilimleri Dergisi, 31: 199-206.

Usta M., Sipahioğlu H.M. ve Güller A. 2016. Doğu Anadolu Bölgesi’nde buğday üretim alanlarındaki bazı buğday virüslerinin multipleks-RT-PCR yöntemi ile araştırılması ve moleküler karakterizasyonu. Bildiriler. Uluslararası Katılımlı Türkiye VI. Bitki Koruma Kongresi, 5-8 Eylül, Konya, 669 s.

Watson M.A. and Mulligan T. 1957. Cereal yellow other virus diseases of Maize dwarf virus in Great Britain. U.S. Dep. Agric. Spec. Rep. Plant Pathol., 6: 12-14.

Yılmaz E. ve Kutluk Yılmaz ND. 2009. Samsun ili buğday üretim alanlarında enfeksiyon oluşturan virüslerin saptanması. Anadolu Tarım Bilimleri Dergisi, 24:67-75.

Yurdakul S., Çalı S. ve Baklacı S. 1987. Orta Anadolu'da buğdayda görülen hastalık belirtilerinin virüs yönünden incelenmesi. Bölge Zirai Mücadele Araştırma Enstitüsü, E-104835 No'lu proje özeti, Ankara, s.1.

Zhang W.W., Cheng Z.M., Xu L., Wu M.S., Waterhouse P., Zhou G.H. and Li S.F. 2009. The complete nucleotide sequence of the Barley yellow dwarf GPV isolate from China shows that it is a new member of the genus Polerovirus. Archives of Virology, 154: 1125-1128. 